\title{
UK insurers oppose moratorium plea on use of genetic data
}

[LONDON] Britain's insurance industry appears to be on a collision course with the government after the industry rejected a proposed two-year moratorium on the use of genetic information in assessing applications for life insurance.

The government's Human Genetics Advisory Commission (HGAC) argued in a report just before Christmas that "substantial research" was needed on the actuarial implications of genetics before estimates of health and lifespan could be drawn from genetic tests.

In a policy statement issued a day after the report, the Association of British Insurers (ABI) said that its 440 member companies continued to oppose a moratorium.

The association's statement emphasized that the ABI's code of practice states that the results of genetic tests are not needed for most types of health, medical and critical illness insurance, and for life insurance cover

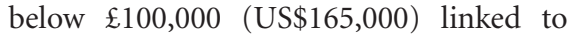

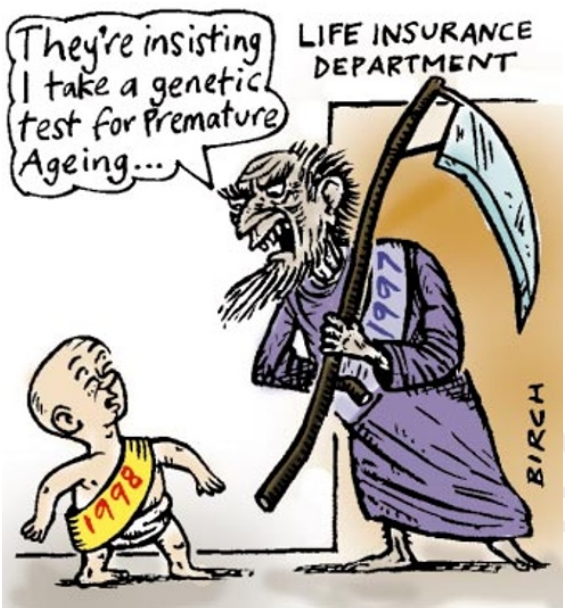

house purchase loans.

But a former member of the House of Commons Select Committee on Science and Technology, whose report on human genetics two years ago led to the creation of the HGAC (see Nature 376, 202; 1995),

\section{Agreement likely on Framework budget}

[MUNICH] After two days of intense negotiations, the European Parliament last month finally approved the European Union's fifth Framework research programme (FP5), due to start next year. The budget will be ECU16.7 billion (US\$18.6 billion) - only slightly higher than the ECU16.3 billion put forward by the European Commission.

As a result, a prolonged battle over the FP5 budget is now unlikely with the counci of ministers, which represents the member states and is keen to keep funding as low as possible. But more problems are likely to arise over the structure of the programme.

To simplify the management of FP5 and concentrate resources, the commission wants to group projects into three thematic programmes: the living world and ecosystems, information and communication technologies, and sustainable growth. These would be accompanied by three 'horizontal programmes' for international cooperation, participation of small and medium-size enterprises, and a training programme called improving human potential.

The council has yet to take a formal position, but has indicated its desire to see five programmes, separating energy and environment from life sciences and giving transport a programme of its own. In contrast, the parliament does not want a special transport programme - but it does want energy and environment to be separated from life sciences into a single programme in two parts, each with its own defined budget line.

Research commissioner Edith Cresson is likely to fight this latter division, concerned that a separate environmental research programme would be vulnerable to a takeover bid from the environment commissioner.

The parliament also wants to change the commission's proposed distribution of the FP5 budget, voting to restrict the money going to nuclear research to ECU1.3 billion, compared to the commission's proposed ECU1.5 billion.

Parliament does not have decisionmaking responsibility for this part of the programme, which is covered by the Eureatom treaty. And differences of opinion between the two major political groups on support for nuclear fusion - the socialists would like to see much less support than the Christian democrats - meant that no position was taken on how this nuclear research budget should be divided.

The council of research ministers will meet on 12 February to decide its own position, which must be agreed unanimously. If all goes well, calls for research proposals could be put out before the end of the year. promised to press for legislation if the call for a voluntary moratorium was ignored.

"The insurance industry is one of the UK's important industries, and we don't want to damage it," says the MP. "But we also want to protect the rights of people. If someone becomes uninsurable, they'll have difficulty in certain fields of work, and in buying a house." In Britain, life insurance is a requirement for some forms of house purchase loan.

The House of Commons science committee gave the insurance industry one year from the publication of its report to come up with proposals on genetic tests, and the HGAC decided to study the issue at its first meeting in February 1997.

Sir Colin Campbell, who chairs the HGAC and is vice-chancellor of the University of Nottingham, says it is not safe to make predictive statements about genetic tests. "It is far too early to be able to reach any conclusions about how genetic testing can be used to predict life expectancy or the onset of illhealth," he says. "Genetic testing is in its infancy."

But Vic Rance, a spokesman for the ABI, says the industry is aware that no genetic test can predict lifespan for most disorders such as heart disease and certain cancers that are caused by a mixture of genes and the environment.

Insurance companies oppose a moratorium as they believe it would be the first step towards a complete ban.

But a spokeswoman for the HGAC says a moratorium is not the same as a ban. "The commission has not at all closed the door on the insurance industry taking in genetic information. They're saying that, in this country, it's too soon."

Insurance companies consider genetic information to be no different from family history information, which is a condition for some policies. The industry says nondisclosure of genetic test results would enable people with genetic illnesses to take out large insurance policies without having to tell the truth about their health. This is known as 'adverse selection'.

They also argue that disclosure has benefits for the insured. A negative test for a person with a family history of a disease will enable that person to obtain insurance cover at standard rather than higher rates.

But the commission's report says the industry can withstand limited adverse selection. It also says there is "widespread concern" that people will refuse to take genetic tests if insurance companies are allowed to see the results.

EhsanMasood 